
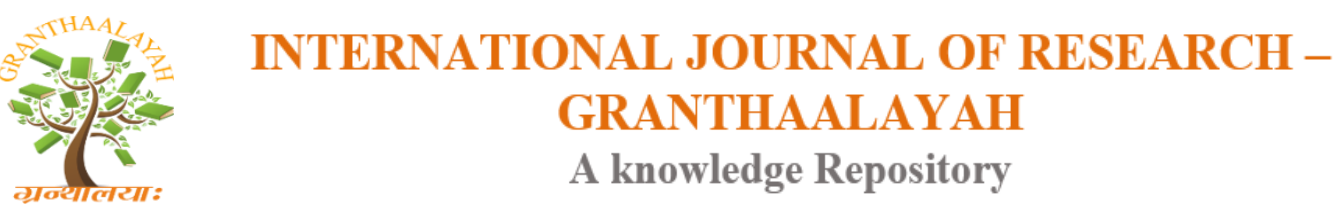

Social

\title{
TESL STUDENT-TEACHERS' PERSPECTIVES OF PRACTICUM PRACTICES IN A MALAYSIAN TEACHER EDUCATION INSTITUTE
}

\author{
Ramesh Sathappan $^{1}$, Dr. Malini Sathappan ${ }^{2}$ \\ ${ }^{1}$ Temenggong Ibrahim Teacher Education Institute, Johor, Malaysia \\ ${ }^{2}$ Tunku Abdul Rahman University College, Kuala Lumpur, Malaysia
}

\begin{abstract}
This study set to find out the challenges faced by TESL students at a local teacher training institute during their first practicum practices at selected Malaysian primary schools for the 2nd semester of the academic year 2017. This research is of significant value, as the 17 studentsteachers' experiences need to be made known; the findings on the transitional move from a safe protected college environment into the unknown territory of school surroundings. Each of these trainee teachers had leapt into the role of a teacher in the 21 st century language class. They would each maintain daily and weekly reflective journals throughout their practicum period to document their teaching concerns and the level of confidence they put into their abilities to teach and manage their primary school students. Thematic areas are discussed in the findings. These findings are triangulated with document reports from their respective supervisors and the school teachers who mentored them. Questionnaires and interviews were conducted. This research enables to shed more lights into the areas of second language teaching in the classroom as the findings would be able to provide more support for future management and development of teacher education. Furthermore, these student-teachers could understand themselves better throughout the month-long practicum. The ability to self-monitor and self-appraise themselves are valuable skills to be acquired by these student-teachers for their personal and autonomous continuous self-assessments to become effective second language teachers.
\end{abstract}

Keywords: Student Teachers; Perspectives; Practicum Practices; Challenges.

Cite This Article: Ramesh Sathappan, and Dr. Malini Sathappan. (2018). "TESL STUDENTTEACHERS' PERSPECTIVES OF PRACTICUM PRACTICES IN A MALAYSIAN TEACHER EDUCATION INSTITUTE." International Journal of Research - Granthaalayah, 6(2), 86-93. https://doi.org/10.5281/zenodo.1186219.

\section{Introduction}

17 TESL student teachers (4 males and 13 females) of a Malaysian local teacher training institute had a taste of their first teaching practicum from 2nd of July, 2017 to 28 September, 2017 in local Chinese national-type primary schools. They are currently in their $5^{\text {th }}$ semester of their degree courses. They will be doing their second practicum in their $6^{\text {th }}$ semester followed by their 
internships in their $8^{\text {th }}$ semester. Thus, it is of paramount importance to carry out this research to shed more light into the challenges that these students had faced during their first month of teaching. The findings from this research would definitely help these students in their future training.

\subsection{The First Practicum Practices}

The first phase of practicum aims to enable student teachers to apply all theories and methods of the teaching and learning processes in actual classroom situations. These student- teachers would experience teaching in actual school environments from the perspective of a teacher. Among the main objectives of this phase (as stated in Jadual 3,2014) are to inculcate positive attitudes and instil professionalism in teaching practices among the student-teachers. It can also sharpen these student-teachers' reflective and self-assessment skills through their portfolio preparations, and finally, to enable these trainees to strategize and conduct co-curriculum activities in school.

\subsection{Significance of the Research and Research Problems}

These student-teachers were divided into 8 Chinese national-type schools, supervised by 8 lecturers from the researchers' teacher training institutes. These trainees were also be cosupervised by experienced school teachers who functioned as their mentors. The lecturers were required to observe their assigned student-teachers twice whereby their school mentors were required to observe them three times. Only during the final occasion, both the lecturers and their school mentors would observe the student-teachers at the same time.

According to Diala, Ibrahim, Yousef, and Ferial (2014), little is known regarding what happens between a student-teacher in or outside the classroom, and if he or she fares badly in the practicum practices, one of the reasons might be due to lack of beneficial advice either from the supervisors or the co-supervising teachers. Even if advice is given, the quality of the advice is being questioned. Furthermore, these student-teachers, face daily challenges, handling conflicts of how much and how often should they seek advice from their supervisors and co-supervisors, without being seen as being weak and thus fearing their marks would be deducted. Therefore, student-teachers' perspectives on their first phase of practicum should be obtained as the findings are crucial in determining the success or failure of these students' teaching the English language classes. Due to this research problem, thus this research is designed. From the findings, greater insights could be gained for the stakeholders, supervisors and co-supervisors alike, to improve on what Diala et al. (2014) would term as the culture of practicum. Two main research questions would be:

Research Question 1: What are the student-teachers' needs of their first practicum practices? Research Question 2: What are the main three challenges faced by student-teachers during their first practicum practices?

As this research was just a preliminary investigation on the student-teacher's perspectives, thus only the above two research questions would be answered in this article. This research would have its limitation; one being it was conducted in a Chinese national-type school context, which means, the study findings is limited based on the instrument used to collect data in a school with 
the Chinese as majority. Thus, the findings might not reflect other types of national schools. Second, the subject participants consisted of only 17 students, whereby, larger numbers would provide more conclusive evidence for research.

\section{Literature Review}

As in Jordan to Diala et. al. (2014), the Malaysian practicum units in local teacher training institutes have also prepared a practicum booklet guide in preparing student-teachers for their practicum practices. This booklet aims to guide these trainees to build professional relationship with the school communities, apart from enabling them to acquire good teaching and learning skills in their daily interactions with their primary school students. In Diala et. al (2014), they had found that the student-teachers in their research on student-teachers perspectives of practicum practices and challenges, the student-teachers as participants had benefitted in the area of the interaction and communication, with students and classroom management skills. They proposed that the duration of the practical experience to be lengthened as the student-teachers felt more comfortable in communicating with children by the end of the practicum practice and the teacher trainees themselves had hoped to have lengthier practicum experiences. By increasing the duration, the researchers claimed that it would bring on positive effect upon the student-teachers' confidence in the actual teaching field. Academic achievement, they had found, had little impact on the success of the student-teachers' practicum stints, thus supporting the view that practical experience is as crucial as the theoretical experience. The common challenges faced by their participants were: the lack of guidance provided by the practicum supervisor, the difficulty in communicating with cooperative teachers, and the inadequate support provided by cooperative teachers. Their study thus suggested to conduct mini-trainings or meetings for university supervisors, cooperative teachers, and student-teachers to discuss and arrange the specific roles and expectations of each of them. As in the case of this research, most of the lecturers who supervised the participants of this research, were experienced lecturers and so were the co-supervisors from the allocated schools. This is the basic requirements from the practicum unit of the local teacher training institute, to have experienced supervisors, thus, the issue of inadequacy of both the lecturers supervising the student-teachers in this research and likewise the teachers as mentors is minimal.

\subsection{Teacher Training Institute in the $21^{\text {st }}$ Century}

In 2008, all local teacher training institute were brought under one central management to standardize quality. Lower student performance in English Language appears to be driven by low proficiency among English language teachers (Malaysian Educational Blueprint, 2013 to 2025). The quality of our future teachers produced by local teacher training institute should be able to fulfil the needs of the nation in building up school children's operational proficiency in English Language. In order to do so, lecturers in teacher training institute, thus, need to ensure that their student-teachers are able to handle second language classroom especially in the $21^{\text {st }}$ century classroom. This is especially crucial in view of Malaysian Educational Blueprint (2013 to 2025) which expresses Malaysian government's efforts in transforming Malaysia's education system with the goal and purpose of education system to equip school children holistically to allow them to succeed in the $21^{\text {st }}$ century. Practicum sessions is a study designed especially for the preparation of future teachers that involves the supervised practical application, supervised 
by experienced educators. In this research, the lecturers from the researchers' teaching training institute and the assigned school teachers (mentors) would be supervising the student-teachers. These sessions provide meaningful field experience as part of teacher preparation program. Student-teachers can self-evaluate and reflect themselves as a form of monitoring their progress from time to time. Goh and Bobbie (2011), in their research on the concerns of student-teachers in Malaysia during teaching practice, had derived eighteen concerns and identified them into four main themes: a) classroom management and student discipline; b) institutional and personal adjustment; c) classroom teaching; and d) student learning. They do agree that the transition from being a student being taught to being a teacher teaching is not easy and adjustments are to be expected. Education courses, they reiterate, should be tailored more to actual school settings and environment. For this research, the researchers would adapt from Goh and Bobbie (2011) and adding a few other salient features based on their research findings.

\section{Methodology}

The 17 student-teachers were sent to 8 Chinese national-type primary schools in Johor Bahru district. Their first phase practicum carries 2 credit with 160 hours for guided- and self-learning. The language classes were about 30 to 60 minutes in duration with average of 8 hours per week for each student-teachers. The 17 student-teachers were informed that their names would be kept confidential. These teacher trainees were also required to maintain a portfolio that would consist on their assigned school background and their records of teaching and learning processes, and co-curriculum activities. They were also required to choose a topic of interest pertaining to the teaching and learning processes during their stints at the allocated Chinese national-type primary schools and to write a journal for 12 weeks addressing the issue that they had chosen. Reflective thinking has been considered a better gauge of a writer's innermost feelings, thus it is able to describe a student-teacher's experiences more vividly when he or she is undergoing a practicum practice (Goh and Bobbie, 2011; Rodman, 2010; Trent, 2010; Etherington, 2009; Faizah, 2008). Thus, this method is largely used in this research to gain deeper insights on the student-teachers' perspectives on their first phase of practicum experiences. The daily and weekly reflective journals were obtained from the student-teachers' record books.

\subsection{The Analysis}

The analysis of the student-teachers' reflective journal writing were done in phases. For the first phase, the researchers would just read with an open mind and re-read until some common themes emerged. For the second phase, a much more analytical comparison would be conducted to distinguish the similarities or differences between the themes which would be highlighted and labelled with different codings. Finally, the chunks of phrases highlighted would be categorised into emerging themes and the findings would later be triangulated with the lecturer (supervisors') and teacher (mentors') evaluative remarks and suggestions. The student-teachers' record books would be analysed if the needs arise to counter check or support some findings that were significant. 


\section{Results and Discussion}

The 17 student-teachers had been given a questionnaire before they started their first phase of their practicum practices. There were 20 constructs in the questionnaires which were derived from the lecturer's copy of evaluation form (refer to Table 1). Findings from these studentteachers' journals were also obtained (refer to Table 2). Below are the results and discussion for Research Question 1 and Research Question 2.

RQ 1: What are the student-teachers' needs for their first phaseof practicum practices? It was found that the student-teachers stayed neutral for Item No. 13 I am able to handle unexpected situations in a classroom (84.2\%). They were not confident in managing the classroom if unexpected events occur during their teaching. Therefore, the researchers concluded that supervisors and teacher mentors need to raise student-teachers' confidence level in managing classrooms which are important elements in a teaching and learning process (Harmer, 2007). These student-teachers also need to be given more exposure to Higher Order Thinking Skills (HOTs) in their teaching, especially in the $21^{\text {st }}$ century language class, due to only $68 \%$ of the student-teachers remained neutral on this item. This phenomenon was supported by various lecturers supervising these student-teachers, whereby, most complained that their trainees failed to incorporate HOTs into their lesson planning. During the interview sessions, the teacher trainees gave feedback that they had not enough time to implement what they had been taught during in their teacher training institute, due to factors such as school events and examinations, therefore, they need longer time span for practicum practices, as stated by Diana et al (2014).

Table 1: Questionnaire on Student-Teachers' Perceptions on First Phase of their Practicum Practices

\begin{tabular}{|l|l|l|l|l|l|l|}
\hline \multirow{2}{*}{$\begin{array}{l}\text { Item } \\
\text { No. }\end{array}$} & \multicolumn{1}{|c|}{$\mathbf{1}$} & $\mathbf{2}$ & $\mathbf{3}$ & $\mathbf{4}$ & $\mathbf{5}$ \\
\hline 1. & \multicolumn{1}{|c|}{ I am able to adapt to any new environment. } & 0 & $\%$ & $\%$ & $\%$ & $\%$ \\
\hline 2. & I have good work ethics and commitment. & 0 & 0 & 15.8 & 63.2 & 21.1 \\
\hline 3. & I am professional and can liase with school authorities. & 0 & 0 & 36.8 & 57.9 & 5.3 \\
\hline 4. & I understand the curiculum and syllabus requirements. & 0 & 10.5 & 42.1 & 42.1 & 5.3 \\
\hline 5. & I am knowledgable about language skills. & 0 & 10.5 & 42.1 & 42.1 & 5.3 \\
\hline 6. & $\begin{array}{l}\text { I understand students needs in the teaching and } \\
\text { learning process. }\end{array}$ & 0 & 10.5 & 47.4 & 36.8 & 5.3 \\
\hline 7. & I am creative in my teaching. & 5.3 & 0 & 17.7 & 21.1 & 0 \\
\hline 8. & I am able to use HOTs in my teaching. & 5.3 & 0 & 68 & 21.1 & 5.3 \\
\hline 9. & I am able use various teaching strategies. & 5.3 & 5.3 & 36.8 & 52.7 & 0 \\
\hline 10. & I am able to vary the tone, intonation and volume. & 0 & 10.5 & 47.4 & 31.6 & 10.5 \\
\hline 11. & I am able to engage students through my teaching. & 0 & 5.3 & 47.4 & 47.4 & 0 \\
\hline 12. & I work well with pupils. & 0 & 5.3 & 26.3 & 68 & 0 \\
\hline 13. & $\begin{array}{l}\text { I am able to handle unexpected situations in a } \\
\text { classroom. }\end{array}$ & 0 & 15.8 & 84.2 & 0 & 0 \\
\hline 14. & $\begin{array}{l}\text { I am able manage time in teaching and learning } \\
\text { process. }\end{array}$ & 0 & 0 & 63.2 & 36.8 & 0 \\
\hline 15. & I am aware of my responsibilities as a teacher. & 0 & 0 & 15.8 & 52.7 & 31.6 \\
\hline
\end{tabular}




\begin{tabular}{|l|l|l|l|l|l|l|}
\hline 16. & $\begin{array}{l}\text { I am able to assess students based on learning } \\
\text { objectives. }\end{array}$ & 0 & 0 & 26.3 & 63.2 & 10.5 \\
\hline 17. & I am a reflective practitioner. & 0 & 0 & 31.6 & 42.1 & 26.3 \\
\hline 18. & I work well in a team. & 0 & 0 & 21.1 & 57.9 & 21.1 \\
\hline 19. & I am able to provide my pupils with pastoral care. & 0 & 0 & 36.8 & 47.4 & 15.8 \\
\hline 20. & I am able to motivate my pupils. & 0 & 0 & 47.4 & 47.4 & 5.3 \\
\hline
\end{tabular}

This questionnaire is to collect your views on Practicum 1. Instruction: Circle the appropriate descriptor

1= Strongly Disagree 2= Disagree 3= Neutral 4= Agree 5=Strongly Agree

\section{RQ 2: What are the main three challenges faced by student teachers during thei first practicum practices?}

From the findings, $68 \%$ of the student-teachers claimed that they could work well with their pupils (refer to Table 1, Item No. 12), however from their reflective journal writings, it was found that classroom management issue was the highest challenge faced by these studentteachers whereby there were 90 occurrences recorded in their journals (refer to Table 2). These student-teachers also faced challenges in applying teaching and learning methodology and strategies with 80 occurrences in their journals. This finding further contradicts with the studentteachers' responses in the questionnaire given to them, with $52.7 \%$ of them agree to Item No. 9 I am able to use various teaching strategies. Therefore, here, one could see there is a wide gap in the student-teachers' perceptions regarding their abilities to carry out their teaching and learning processes well. However, the student-teachers were aware that they might faced problems in managing the time during their first phase of practicum teaching, because, only $36.8 \%$ of them agree that they could manage the time well, and this was supported by the findings from their journal writings, whereby, there were 69 occurrences of these student-teachers having issue on time management during the practicum sessions.

Table 2: Contributing Factors from Student-Teachers' Journal Writings

\begin{tabular}{|c|c|c|}
\hline Emerging Themes & Contributing Factors & Occurences \\
\hline \multirow{3}{*}{$\begin{array}{lll}\text { Classroom management } & \text { student } \\
\text { discipline } & & \end{array}$} & Classroom management & 90 \\
\hline & Reward system & 27 \\
\hline & Addresses destructive behaviours & 33 \\
\hline \multirow[t]{13}{*}{ Classroom teaching } & Time management & 69 \\
\hline & Learning outcome & 1 \\
\hline & Quality of worksheets & 24 \\
\hline & $\begin{array}{l}\text { Teaching methodology and } \\
\text { strategies. }\end{array}$ & 80 \\
\hline & Moral values & 8 \\
\hline & HOTs & 8 \\
\hline & Teaching aids & 20 \\
\hline & Able to link theory to practice (stated) & 31 \\
\hline & Group activities & 62 \\
\hline & Writing lesson plan & 1 \\
\hline & Integration of learning standards & 1 \\
\hline & Smartboard/ICT/Powerpoint & 32 \\
\hline & Classroom environment & 8 \\
\hline
\end{tabular}




\begin{tabular}{|c|c|c|}
\hline \multirow[t]{14}{*}{ Teacher's attributes } & Voice projection & 23 \\
\hline & Language proficiency & 6 \\
\hline & Pronunciation issues & 11 \\
\hline & Grammar awareness & 1 \\
\hline & Remembering pupils' names & 8 \\
\hline & Nervous/worry/relax & 10 \\
\hline & Instructions & 41 \\
\hline & Body language & 3 \\
\hline & Scaffolding & 2 \\
\hline & Not prepared & 9 \\
\hline & Forgetful & 1 \\
\hline & Questioning techniques & 4 \\
\hline & Personality & 2 \\
\hline & Teaching style & 1 \\
\hline \multirow[t]{5}{*}{ Student learning } & Student awareness & 26 \\
\hline & Problem solving & 3 \\
\hline & Find ways to make pupils understand & 2 \\
\hline & Addressing weak students & 7 \\
\hline & Students' proficiency & 21 \\
\hline \multirow[t]{5}{*}{ Institutional adjustments } & $\begin{array}{l}\text { Social relationship with the school } \\
\text { staff }\end{array}$ & 5 \\
\hline & Seek supervisor's advice & 1 \\
\hline & Seek mentor's advice & 7 \\
\hline & Portfolio requirements & 1 \\
\hline & School information & 1 \\
\hline \multirow[t]{13}{*}{ Personal adjustments } & Preparation & 3 \\
\hline & Confidence & 2 \\
\hline & Too low expectations & 2 \\
\hline & Too high expectations & 8 \\
\hline & More firm & 16 \\
\hline & Teacher-centred/Student-centred & 13 \\
\hline & Used school experience & 1 \\
\hline & Do more research & 3 \\
\hline & Seek advice from seniors & 1 \\
\hline & Observant, flexible and creative & 2 \\
\hline & Real life teaching & 12 \\
\hline & Lecture notes & 1 \\
\hline & Role Model & 1 \\
\hline
\end{tabular}

\section{Conclusion}

The overall findings of this study suggests interesting insights on student-teachers' needs and challenges to fill up the gap from their institution to school. The findings showed that these student-teachers' highest need is to be more confident to face unforeseen circumstances that unfold during their teaching sessions and also the HOTs elements to be incorporated into their 
lesson plans. The researchers found that these student-teachers failed to address HOTs in their reflective writings,

with only 8 occurrences, whereby, majority of them remained neutral regarding HOTs. From this, the researchers could conclude that these student-teachers did not focus much on HOTs, which was also agreed by the lecturers who were interviewed.

The findings of this research also shown that these student-teachers also face the challenges of managing the classroom, teaching methodology and strategies, and time management. The researchers believe that there is indeed a gap of what these student-teachers learned in their teacher training institute and the actual scenario during their first phase of practicum experience. To fill this gap, the researchers suggest that further in-depth studies and also perhaps a larger qualitative study through interviews and classroom observations of the practicum students could be conducted to identify the strategies used by these students to overcome their concerns. This could be carried out further during their second phase of practicum sessions due to longer time frame.

\section{References}

[1] Diala, H., Ibrahim, A., Yousef A., and Ferial, A.A. (2014). Student-teachers' Perspectives of Practicum Practices and Challenges. European Scientific Journal, 10(13), 191-214.

[2] Etherington, M. (2009). Swapping the Boardroom for the Classroom. Australian Journal of Teacher Education, 34(4), 39-59.

[3] Faizah, A.M. (2008). The Use of Reflective Journals in Outcome-based Education during the Teaching Practicum. Malaysian Journal of ELT Research, 4, 32-42.

[4] Goh, P.S. and Bobbie, M. (2011). Listening to the Concerns of Student-teachers in Malaysia during Teaching Practice. Australian Journal of Teacher Education, 36(3), 12-23.

[5] Harmer, J. (2007). The Practice of English Language Teaching (4th ed). Edinburgh: Pearson Education Limited.

[6] Jadual 3 (2014). Ringkasan Maklumat Bagi Setiap Kursus/Modul. Institut Pendidikan Guru.

[7] Malaysian Educational Blueprint, 2013 to 2025. (2012). Kementerian Pendidikan Malaysia.

[8] Rodman, G.J. (2010). Facilitating the Teaching-Learning Process through the Reflective Engagement of Pre-service teachers. Australian Journal of Teacher Education, 35(2), 20-34.

[9] Trent, J. (2010). "My Two Maseters": Conflict, Contestation, and Identity Construction within a Teaching Practicum. Australian Journal of Teacher Education, 35(7), 1-14.

*Corresponding author.

E-mail address: jhnmesh@yahoo.com 